\title{
LEBER'S HEREDITARY OPTIC NEUROPATHY: IMPLICATIONS OF THE SEX RATIO FOR LINKAGE STUDIES IN FAMILIES WITH THE 3460 ND1 MUTATION
}

\author{
G. C. M. BLACK ${ }^{1}$, I. W. CRAIG ${ }^{1}$, R. J. OOSTRA ${ }^{2}$, S. NORBY ${ }^{3}$, T. ROSENBERG ${ }^{4}$, \\ K. MORTEN ${ }^{5}$, A. LABORDE ${ }^{1}$ and J. POULTON ${ }^{5}$ \\ Oxford; Amsterdam, The Netherlands; and Copenhagen and Hellerup, Denmark
}

\begin{abstract}
SUMMARY
Leber's hereditary optic neuropathy (LHON), which is associated with mutations in mitochondrial DNA (mtDNA), is commoner in males than females. A study of over 30 LHON families with a mutation at position 3460 of mtDNA demonstrates a significantly decreased male excess from that generally quoted, with evidence for a marked bias in the ascertainment of males over females. This has implications for the analysis of those factors which give rise to the male bias.
\end{abstract}

Leber's hereditary optic neuropathy (LHON) is an uncommon condition characterised in the late stage of the disease by bilateral optic atrophy, usually subacute in onset. In general, both eyes are involved sequentially, resulting in marked loss of central vision. The disease passes only through the maternal line and is associated with mitochondrial DNA (mtDNA) mutations. Several such mutations have now been described, all lying within protein reading frames of mtDNA: the most common are at positions $3460,{ }^{1,2} 11778^{3}$ and $14484 .^{4}$ These mutations are estimated to account for $15 \%, 50 \%$ and $10 \%$ of LHON pedigrees respectively.

The disease is more common in males than females, and in Europe $85 \%$ of patients are male $(5.6: 1) .^{6-8}$ The age of onset in males is on average 215 years earlier than females. This unequal sex distribution is not explained by mitochondrial

From: ${ }^{1}$ Genetics Laboratory, Department of Biochemistry, University of Oxford, South Parks Road, Oxford, UK; ${ }^{2}$ Department of Ophthalmogenetics, The Netherlands Ophthalmic Research Institute, Amsterdam, The Netherlands; ${ }^{3}$ Department of Forensic Genetics, University of Copenhagen, Denmark;

${ }^{4}$ National Eye Clinic for the Visually Impaired, Hellerup,

Denmark; ${ }^{5}$ Department of Paediatrics, John Radcliffe Hospital,

Headington, Oxford, UK.

Correspondence to: J. Poulton, Department of Paediatrics,

John Radcliffe Hospital, Headington, Oxford OX3 9DU, UK. inheritance; other factors, either genetic or environmental, also appear to influence the phenotype.

Data presented here suggest that the sex distribution varies for the different mitochondrial mutations. Furthermore, there is evidence for a clinical bias towards diagnosing LHON in males.

\section{METHODS}

Preparation of Genomic DNA

DNA from peripheral blood was extracted by standard procedures. ${ }^{9}$ Where we were unable to obtain blood from individuals of family L2, DNA was extracted from buccal mouthwashes. ${ }^{0}$

\section{Mutation Analysis}

Polymerase chain reaction (PCR) was carried out in $50 \mu \mathrm{l}$ reaction volumes overlaid with paraffin oil. The reaction mix consisted of 100-200 ng of genomic DNA, $0.5-1 \mu \mathrm{M}$ of each primer, $5 \mu \mathrm{l}$ of Boehringer $10 \times$ concentration reaction buffer, $0.2 \mathrm{mM}$ of each dNTP and $0.25 \mu \mathrm{l}$ of Taq polymerase (Boehringer). Samples were processed through 29 cycles of denaturation $\left(94^{\circ} \mathrm{C}\right.$ for 60 seconds), annealing $\left(55^{\circ} \mathrm{C}\right.$ for 60 seconds) and elongation $\left(74^{\circ} \mathrm{C}\right.$ for 1 minute).

The primers, according to position on the mtDNA, were 3275-3295 (forward) and 3557-3577 (reverse). A product of 302 base pairs is amplified, and the 3460 ND1 mutation, G2 $\longrightarrow$ A, removes a BsaH1 (New England Biolabs) restriction enzyme site, which, when cleaved, produces fragments of 117 and 185 base pairs. The fragments were resolved on a $2 \%$ agarose gel, and stained with ethidium bromide and photographed.

\section{MtDNA Analysis}

The mtDNA point mutations at positions 4216, 

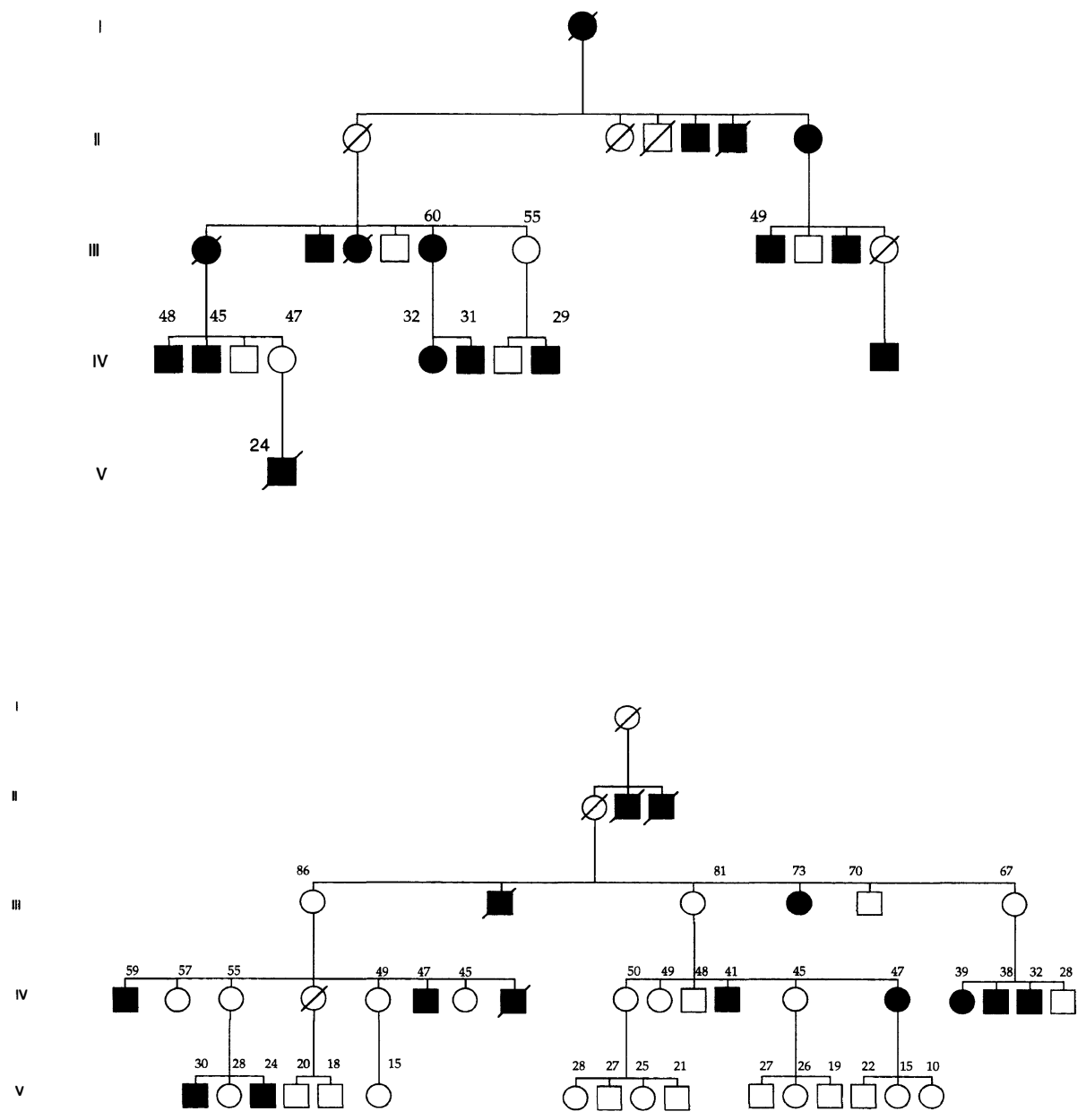

Fig. 1. Pedigrees of Leber's hereditary optic neuropathy. Top: English 3460 Pedigree L1. Bottom: Basque 3460 Pedigree L2. Ages of all individuals are indicated.

11 778, 13 708, 15257 and 15812 were screened for by PCR using the conditions described above. Primer positions and restriction site analysis are given in Table I.

\section{RESULTS}

Both new families investigated (Fig. 1) have the 3460 mutation and are wild-type at positions 4216,11778 , 13708,15257 and 15812 . Of a total of 70 individuals related to the maternal lines ( 33 female and 37 male), $31(44 \%)$ were clinically affected. Of these, 22 were male $(71 \%)$ and 9 female (29\%). Because the sex

Table I. LHON mtDNA point mutation analysis

\begin{tabular}{llcc}
\hline Gene & \multicolumn{1}{c}{ Mutation } & PCR primers & $\begin{array}{c}\text { Restriction site } \\
\text { loss or gain }\end{array}$ \\
\hline ND1 & GA $\longrightarrow(3460)$ & $3275-3295$ & BsaH1 (loss) \\
& & $3557-3577$ & \\
ND1 & TC $\longrightarrow(4216)$ & $4041-4050$ & AflIII (gain) \\
& & $4300-4319$ & \\
ND4 & GA $\longrightarrow(11778)$ & $11632-11651$ & MaeIII (gain) \\
& & $11843-11862$ & \\
ND5 & GA $\longrightarrow(13708)$ & $13591-13610$ & Scrf (loss) \\
& & $13730-13750$ & \\
cyb b & GA $\longrightarrow(15$ 812) & $15730-15749$ & RsaI (loss) \\
& & $15980-15999$ & \\
cyt b & GA $\longrightarrow(15257)$ & $14900-14919$ & AccI (loss) \\
& & $15329-15348$ & \\
\hline
\end{tabular}

distribution for these families differs from that generally quoted we compiled data on the distribution between the sexes for as many 3460 patients as possible (Table II).

These data give ratios of $3.66: 1$ (77.2\% males) for those with classical disease or, including those with peripapillary micrangiopathy (the second figure), 3.03 : 1 (75.2\% males). These figures are similar to those seen for the two families discussed above. Combining the data in Table II with those from the families shown in Fig. 1, for all those affected with classical LHON, gives 119 males and 37 females - a ratio of $3.22: 1$ (76.2\% males) amongst 33 families.

Table II. Numbers of affected individuals with the 3460 mutation

\begin{tabular}{lcccc}
\hline & Male & Female & $\begin{array}{c}\text { No. of } \\
\text { families }\end{array}$ & $\begin{array}{c}\text { Singleton } \\
\text { families M:F }\end{array}$ \\
\hline Finnish $^{2}$ & $9(21)$ & $5(13)$ & 3 & $0: 0$ \\
English $^{1,14}$ & 19 & 6 & 9 & $2: 0$ \\
Australian & 5 & 2 & 2 & $1: 0$ \\
American $^{19}$ & 11 & 1 & 9 & $6: 1$ \\
Danish $^{20}$ & 22 & 9 & 2 & $0: 0$ \\
Dutch $^{20}$ & 31 & 5 & 8 & $3: 0$ \\
Total & $97(109)$ & $28(36)$ & 33 & $12: 1$ \\
\hline
\end{tabular}

For the Finnish study, the first figure is those with classical LHON; the second, bracketed figure includes those with peripapillary micrangiopathy. 


\section{DISCUSSION}

The data presented here suggest that the observed sex distribution in families, both published and unpublished, carrying the 3460 mutation is around 3 : 1 (males : females). Interestingly, 12 of the families contain only one affected member, and of these only one is female. This suggests considerable clinical bias towards males in the diagnosis of sporadic cases of LHON. In order to minimise this bias, the singleton families were excluded from the analysis to give a ratio of $2.97: 1$. This differs significantly $(p<0.001)$ from that generally quoted (i.e. $85 \%$ or $5.66: 1$ ) and is likely to reflect the true distribution for the 3460 mutation.

Although life style and/or physiological differences might be invoked, an X-linked recessive factor interacting with mitochondrially encoded factors would be an attractive hypothesis to explain the observed sex ratio. ${ }^{11}$ However, several studies have failed to demonstrate linkage to any region of the $\mathrm{X}$ chromosome. ${ }^{12-15}$ We suggest that these studies are inconclusive and have not ruled out an X-linked susceptibility locus. There is mounting evidence that multiple predisposing factors are involved in the aetiology of LHON. The following might therefore confound such analysis and conceal linkage.

Incorrect estimations of penetrance may have a profound effect on the evaluation of linkage data. As LHON may manifest at any time between the ages of 10 and 65 years, only a small number of relatives can confidently be classified as unaffected.

Tissue-specific factors may be directly relevant to the manifestation of the disease, but must be studied indirectly as the optic nerve can only be sampled post-mortem. These include mtDNA heteroplasmy and, if an X-linked factor is involved, the $\mathrm{X}$ inactivation patterns of females.

Furthermore, recent evidence suggests that certain mtDNA 'polymorphisms' might affect the phenotype, perhaps in a cumulative fashion. ${ }^{16}$ Thus defining truly homogeneous groups may as yet be impossible. Our data show that the sex distribution for the 3460 mutation differs from other groups of LHON. This strongly suggests that the influence of the predisposing factors varies according to their interaction with the different mtDNA mutations. Thus families with different mitochondrial mutations should not be grouped together for linkage analysis.

Lastly, in the case of other X-linked ocular diseases, such as $\mathrm{X}$-linked retinitis pigmentosa, distinct loci have been shown to cause similar diseases ${ }^{17}$ - there might be more than one nuclear/ $\mathrm{X}$-linked factor involved.

Thus conventional genetic analysis might well fail to demonstrate linkage to regions which nevertheless are involved in the disease. Such analysis may therefore be inappropriate for the identification of any interacting nuclear gene. The existence of an Xlinked susceptibility gene remains a plausible hypothesis. A more fruitful approach might be to look at the co-segregation of candidate nuclear genes which are known to interact with the mitochondrion. Examples include the pyruvate dehydrogenase subunit $\mathrm{E} 1 \alpha$ and a possible $\mathrm{X}$-linked locus that complements defects in complex I of the electron transport chain and which has been described in mouse-hamster hybrids. ${ }^{18}$ Characterisation of such a locus would represent an interesting starting point for study.

G.C.M.B. is supported by the British Retinitis Pigmentosa Society, J.P./K.M. by The Wellcome Trust, and S.N. by the Danish National Association against Eye Diseases and Blindness (Hotelejer Carl Larson og hustru Nicoline Larsens Mindelegat). We would like to thank David Mackey, Joan Bronte-Smith and Erik Kann for help in collecting family data.

Key words: Leber's hereditary optic neuropathy, Mitochondrial DNA, Sex ratio.

\section{REFERENCES}

1. Huoponen K, Vilkki J, Aula P, Nikoskelainen EK, Savontaus M-L. A new mtDNA mutation associated with Leber hereditary optic neuroretinopathy. Am J Hum Genet 1991;48:1147-53.

2. Howell N, Bindoff LA, McCullough DA, Kubacka I, Poulton J, Mackey D, et al. Leber hereditary optic neuropathy: identification of the same mitochondrial ND1 mutation in six pedigrees. Am J Hum Genet 1991;49:939-50.

3. Wallace DC, Singh G, Lott MT, Hodge JA, Schurr TG, Lezza AMS, Elsas LJ. Mitochondrial DNA mutation associated with Leber's hereditary optic neuropathy. Science 1988;242:1427-30.

4. Mackey D, Howell N. A variant of Leber hereditary optic neuropathy characterised by recovery of vision and by an unusual mitochondrial genetic etiology. Am J Hum Genet 1992;51:1218-28.

5. Howell N, Halvorson S, Burns J, McCullough DA, Poulton J. When does bilateral optic atrophy become Leber Hereditary Optic Neuropathy? Am J Hum Genet 1993;53:959-63.

6. Bell J. The treasury of human inheritance, vol. II, part 4. Cambridge: Cambridge University Press, 1931.

7. Lundsgaard R. Leber's disease: a genealogic, genetic and clinical study of 101 cases of retrobulbar optic neuritis in 20 Danish families. Dissertation, Copenhagen, 1944.

8. van Senus AHC. Leber's disease in the Netherlands. Dissertation, Rotterdam, 1963.

9. Maniatis T, Fritch EF, Sambrook J. Molecular cloning: a laboratory manual. New York: Cold Spring Harbor Laboratory, 1982.

10. Tobal K, Layton DM, Mufti GJ. A non-invasive isolation of constitutional DNA for genetic analysis. Lancet 1989;i:1281.

11. Bu X, Rotter JI. X-chromosome linked and mitochondrial gene control of Leber hereditary optic neuropathy: evidence from segregation analysis for dependence of $\mathrm{X}$ chromosome inactivation. Proc Natl Acad Sci USA 1991;88:8198-202.

12. Chen JD, Cox I, Denton MJ. Preliminary exclusion of 
an X-linked gene in Leber optic atrophy by linkage analysis. Hum Genet 1989;82:203-7.

13. Carvalho MRS, Muller B, Rozer E, Berninger T, Kommerell G, Blankenagel A, et al. Leber hereditary optic neuroretinopathy and the X-chromosomal susceptibility factor: no linkage to DXS7. Hum Hered 1992;42:316-20.

14. Sweeney MG, Davis MB, Lashwood AM, Brockington M, Toscano A, Harding AE. Evidence against an Xlinked locus close to DXS7 determining visual loss susceptibility in British and Italian families with Leber hereditary optic neuropathy. Am J Hum Genet 1992; 51:741-8.

15. Juvonen V, Vilkki J, Aula $P$, Nikoskelainen E, Savontaus M-L. Reevaluation of the linkage of an optic atrophy susceptibility gene to X-chromosomal markers in Finnish families with Leber hereditary optic neuroretinopathy (LHON). Am J Hum Genet 1993;53: 289-92.

16. Brown MD, Voljavac AS, Lott MT, Torroni A, Yang
C-C, Wallace DC. Mitochondrial DNA complex I and III mutations associated with Leber's hereditary optic neuropathy. Genetics 1992;130:163-73.

17. Ott J, Bhattacharya S, Chen JD, et al. Localising multiple $\mathrm{X}$ chromosome-linked retinitis pigmentosa loci using multilocus homogeneity tests. Proc Natl Acad Sci USA 1990;87:701-4.

18. Day CE, Scheffler IE. Mapping of the genes of some of the components of the electron chain (complex I) on the $\mathrm{X}$ chromosome of mammals. Somat Cell Genet 1982;8:691-707.

19. Johns DR, Smith KH, Miller NR. Leber's hereditary optic neuropathy: clinical manifestations of the 3460 mutation. Arch Ophthalmol 1992;110:1577-81.

20. Oostra RJ, Bolhuis PA, Zorn-Ende G, De KokNazaruh MM, Bleeker-Wagemakers EM. Leber's hereditary optic neuropathy: no significant evidence for primary or secondary pathogenicity of the 15257 mutation. Hum Genet 1995;(in press). 